\title{
Cyclanthaceae no estado do Pará, Brasil
}

\author{
Eduardo da Silva Leal ${ }^{1,2}$ e Rafaela Campostrini Forzza ${ }^{1}$
}

Recebido em 29/07/2011. Aceito em 4/07/2012

\begin{abstract}
RESUMO
(Cyclanthaceae no estado do Pará, Brasil). Cyclanthaceae apresenta distribuição exclusiva na região neotropical sendo bem diversificada nas terras baixas das florestas pluviais tropicais, ocorrendo do sul do México até a Mata Atlântica do sul do Brasil. Consistem de ervas terrestres, epífitas, hemiepífitas ou lianas. O tratamento taxonômico de Cyclanthaceae no Pará foi baseado em coleções de herbário, trabalhos de campo e consulta a bibliografia referente à família. Foram registradas 11 espécies: Asplundia altiscandens E.S. Leal, A. fanshawei (Maguire) Harling, A. glandulosa (Gleason) Harling, A. heteranthera Harling, A. latifrons (Drude) Harling, A. schizotepala Harling, A. xiphophylla Harling, Cyclanthus bipartitus Poit. ex A. Rich., Evodianthus funifer (Poit.) Lindm., Ludovia lancifolia Brongn. e Thoracocarpus bissectus (Vell.) Harling. São apresentadas chave de identificação, descrições e ilustrações das espécies, além de comentários sobre distribuição geográfica, hábitat e período de floração e frutificação.
\end{abstract}

Palavras-chave: Amazônia, Monocotiledôneas, Pandanales, taxonomia

\begin{abstract}
(Cyclanthaceae in Pará State, Brazil). Cyclanthaceae is a family with a distribution exclusively in the Neotropics and is well diversified in lowland rainforests, occurring from southern Mexico to the Atlantic Forest of southern Brazil. The family consists of terrestrial herbs, epiphytes, hemiepiphytes and lianas. This taxonomic treatment of the Cyclanthaceae from the state of Pará was based on herbarium specimens, fieldwork, and the literature. Eleven species were recorded: Asplundia altiscandens E.S. Leal, A. fanshawei (Maguire) Harling, A. glandulosa (Gleason) Harling, A. heteranthera Harling, A. latifrons (Drude) Harling, A. schizotepala Harling, A. xiphophylla Harling, Cyclanthus bipartitus Poit. ex A. Rich., Evodianthus funifer (Poit.) Lindm., Ludovia lancifolia Brongn. and Thoracocarpus bissectus (Vell.) Harling. An identification key, descriptions and illustrations of species are presented. Additional information on the geographic distribution, habitat, and flowering and fruiting periods are also provided.
\end{abstract}

Key words: Amazon, Monocots, Pandanales, taxonomy

\section{Introdução}

Cyclanthaceae está posicionada na ordem Pandanales (APG III 2009) com distribuição exclusiva na região neotropical, ocorrendo do sul do México até a Floresta Atlântica do sul do Brasil (Harling 1958; Leitman \& Leal 2009). São ervas terrestres, epífitas, hemiepífitas ou lianas, bem diversificadas nas terras baixas das florestas pluviais e na região Andina, podendo ocorrer até $3.000 \mathrm{~m}$ de altitude e preferindo locais úmidos (Harling 1958). A família possui cerca de 240 espécies distribuídas em doze gêneros e no Brasil, está representada por 30 espécies e nove gêneros, ocorrendo principalmente nas florestas Amazônica (21 spp.) e Atlântica (10 spp.) e 12 espécies são endêmicas do território brasileiro (Leal 2010). A primeira classificação infra-familiar foi publicada por Drude
(1881), que propôs duas tribos, Carludoviceae e Cyclantheae, baseado na estrutura da inflorescência. Harling (1958) elevou as tribos à subfamília, sendo essas: Cyclanthoideae, com apenas uma espécie (Cyclanthus bipartitus) caracterizada por possuir flores estaminadas e pistiladas dispostas em anéis alternados no espádice, e Carludovicoideae, com todos os demais gêneros, caracterizada por possuir uma flor pistilada circundada por quatro flores estaminadas.

No Brasil, o conhecimento sobre as Cyclanthaceae restringe-se à Flora Brasiliensis (Drude 1881), checklists e a dois trabalhos de cunho florístico-taxonômico: Gomes \& Mello-Silva (2006), realizado no âmbito do Projeto Flora da Reserva Ducke, e ao tratamento para a Flora Fanerogâmica do Estado de São Paulo (Gomes \& Giulietti 2003). O objetivo deste trabalho é apresentar os resultados do estudo

\footnotetext{
${ }^{1}$ Jardim Botânico do Rio de Janeiro, Rio de Janeiro, RJ, Brasil

${ }^{2}$ Autor para correspondência: edu_engflor@yahoo.com.br
} 
taxonômico realizados com as espécies de Cyclanthaceae do Pará, que correspondem a cerca de $1 / 3$ da diversidade específica da família registrada no Brasil.

\section{Material e métodos}

Os dados morfológicos e ecológicos foram obtidos da análise de cerca de 290 exsicatas depositadas nos herbários IAN, INPA, MG, R, RB e UFACPZ, bem como de imagens de espécimes dos herbários B, GOET, K, MBM, NY, P e $S$ (acrônimos segundo Thiers 2011) e observações feitas durante as coletas.

A altura das plantas, quando hemiepífitas, foi tomada a partir da fixação mais alta no forófito. A terminologia utilizada seguiu Harling (1958) e Stearn (1983) e, para a forma dos segmentos foliares, Ellis et al. (2009). A descrição dos segmentos foliares refere-se apenas às partes livres. A divisão das lâminas, expressas em porcentagem, foi calculada dividindo a profundidade da partição da lâmina pelo tamanho do segmento foliar. As medidas das estruturas foram realizadas segundo Eriksson (1995). Em muitos casos, o número de espatas na inflorescência é dado a partir do número de cicatrizes no pedúnculo, após a queda das mesmas. As flores geralmente têm diferença de tamanho e forma no ápice e na base da inflorescência. Assim, para a descrição destas foram utilizadas flores da região mediana do espádice. As inflorescências e infrutescências tiveram as suas medidas de largura feitas na região mediana da estrutura. Os períodos de floração e frutificação das espécies foram baseados nos espécimes analisados.

\section{Tratamento Taxonômico}

Cyclanthaceae Poit. ex A. Rich., Dict. Class. Hist. Nat. 5: 222.1824.

Ervas terrestres, hemiepífitas, epífitas ou lianas, acaulescentes, nesse caso rizomatosas ou caule aéreo ereto ou rastejante, em lianas caule densamente anelado. Folhas alternas, dísticas ou espiraladas, raramente inteiras, bífidas, bissectas ou bipartidas, 1-3-costadas; pecíolo com bainha envolvendo o caule, epiderme da bainha variando em textura e coloração, se desprendendo ou não. Espádice, axilar ou terminal, pedunculado, envolvido por 3 a 8 espatas, cimbiformes, lanceoladas e apiculadas. Flores monoclinas no mesmo espádice, estaminadas e pistiladas, em forma de mosaico na inflorescência; flor pistilada rodeada por quatro flores estaminadas ou em ciclos alternos, nesse caso reduzidas. Flores estaminadas simétricas ou assimétricas, pediceladas ou sésseis, pedicelo excêntrico em flores assimétricas, receptáculo côncavo ou aplanado, perianto com poucos a muitos lobos, raro dois verticilos, lobos do perianto com glândulas; filete e conectivo inconspícuos, antera globosa a filiforme, variando de tamanho na mesma flor. Flores pistiladas tricíclicas, tépalas 4 , às vezes reduzidas, conatas ou livres, persistentes, 4 estaminódios opostos às tépalas, filiformes, caducos; estiletes ausentes ou 4, livres ou fundidos em 1, 4 estigmas, alternos às tépalas, variando em forma, maiores ou menores que as tépalas; ou flores reduzidas, compartilhando câmara ovariana, em um ciclo. Infrutescência cilíndrica ou esférica, bagas coalescentes ou livres, com perigônio, estigma e estilete persistentes.

\section{Chave de identificação para as espécies de Cyclanthaceae do Pará}

1. Lâmina foliar 2-costada, flores estaminadas e pistiladas dispostas em ciclos alternos no espádice

..8. Cyclanthus bipartitus (Cyclanthoideae)

1. Lâmina foliar 1-3-costada, flores estaminadas e pistiladas dispostas em arranjos espirais, 4 flores estaminadas envolvendo 1 flor pistilada

Carludovicoideae

2. Epífita, folhas dísticas, lâmina foliar inteira, coriácea, flores femininas com tépalas reduzidas

10. Ludovia lancifolia

2. Terrestre, hemiepífita ou liana, folhas espiraladas, lâmina foliar partida, às vezes inteiras e partidas em ramos jovens, não-coriácea, flores femininas com tépalas desenvolvidas.

3. Inflorescência terminal, espatas distribuídas logo abaixo do espádice, flores pistiladas e bagas livres 9. Evodianthus funifer

3. Inflorescência axilar, espatas distribuídas ao longo do pedúnculo, flores pistiladas e bagas coalescentes.

4. Liana, caule aéreo, até $30 \mathrm{~m}$ compr., densamente anelado, lâmina 1-costada, espatas 5-8, aumentando de tamanho em direção ao ápice do pedúnculo

11. Thoracocarpus bissectus

4. Hemiepífitas ou terrestres, acaulescente, caule rastejante ou caule aéreo, até $10 \mathrm{~m}$ compr., lâminas 1-3-costado, espatas 3-4, diminuindo de tamanho em direção ao ápice do pedúnculo

Asplundia

5. Flores estaminadas simétricas, folha 1-costada

Asplundia subg. Choanopsis

6. Pedúnculo $4-5 \mathrm{~cm}$ na infrutescência, tépalas fimbriadas nas bagas 6. A. schizotepala

6. Pedúnculo ca. $6 \mathrm{~cm}$ na infrutescência, tépalas inteiras nas bagas 4. A. heteranthera

5. Flores estaminadas assimétricas, folha 3-costada Asplundia subg. Asplundia

7. Epiderme da base do pecíolo e bainha se desprendendo, amarela ou alaranjada, quebradiça, brilhosa.

8. Hemiepífita, lâmina foliar linear-lanceolada, segmento 3-7 cm larg., partida quase até a base 7. A. xiphophylla 
8. Terrestre, lâmina foliar oval, segmento $14-16 \mathrm{~cm}$ larg., partida ca. $65 \%$ do compr. 5. A. latifrons

7. Epiderme da base do pecíolo e bainha, uniforme, marrom, não se desprendendo, não quebradiça e não brilhosa.

9. Terrestre, pecíolo fortemente alado 3. A. glandulosa

9. Hemiepífita, pecíolo sem alas ou levemente alado.

10. Lâmina foliar ca. $40 \mathrm{~cm}$ compr., pecíolo ca. $35 \mathrm{~cm}$ 2. A. fanshawei 10. Lâmina foliar ca. $75 \mathrm{~cm}$ compr., pecíolo ca. $50 \mathrm{~cm}$ 1. A. altiscandens

1. Asplundia altiscandens E.S. Leal, Nordic J. Bot. 29: 687690. 2011 [2012].

Ilustração: Leal (2011)

Hemiepífita até $10 \mathrm{~m}$ alt.; caule ca. $2 \mathrm{~cm}$ diâm.; raízes grampiformes. Folhas alterno-espiraladas, bífidas; lâmina ca. $75 \mathrm{~cm}$ compr., partidas até ca. $65 \%$ do compr., distintamente 3-costadas, costas laterais mais concentradas no meio da lâmina, segmento 10-15 cm larg., lanceolado a oblanceolado, ápice agudo, base decurrente, face abaxial com 13 nervuras secundárias evidentes; pecíolo 40-48 cm compr., porção proximal canaliculada e alada; bainha ca. $5 \mathrm{~cm}$ larg., epiderme da bainha, pedúnculo e pecíolo da mesma cor, não desprendendo, não brilhosa, não quebradiça. Espádice axilar, pedúnculo ca. $8,5 \mathrm{~cm}$ compr., bainha bem desenvolvida em sua base, triangular, cimbiforme, ca. $5 \mathrm{~cm}$ compr.; espatas 3-4, até $2 \mathrm{~cm}$ abaixo do espádice, na antese localizadas mais próximas, em fruto mais afastadas, cimbiformes, apiculadas a acuminadas, subiguais, 6,5-8 x 2,5 $\mathrm{cm}$; espádice cilíndrico, ca. 3 x 1,5 cm. Flores estaminadas assimétricas, 3-4 x $2 \mathrm{~mm}$, pedicelo excêntrico, receptáculo aplanado, perianto 6-7 lobos, tépalas 0,5-0,7 x 1-2 mm; estames 20-30, subiguais, anteras $0,5-1 \mathrm{~mm}$ compr., filete e conectivo inconspícuos. Flores pistiladas conatas, ca. 3 mm diâm., tépalas livres, truncadas a obtusas, às vezes de ápice acuminado, recurvadas sobre os estigmas, ca. 2 x 1 $\mathrm{mm}$; estiletes livres, ca. 1,5 mm compr.; estigma ca. 1,5 mm compr., oblongo em vista superior, protegido entre as tépalas; estaminódios 7-8 cm compr., amarelo-esbranquiçados. Infrutescência pêndula, pedúnculo $10-15 \mathrm{~cm}$ compr., espádice cilíndrico 3-5,5 x 1,5-2,5 cm; bagas coalescentes, tépalas conatas, truncadas, ca. 4 × $3 \mathrm{~mm}$, menores que o estigma; estigma, ca. $1,5 \times 1 \mathrm{~mm}$, levemente acuminado, elíptico a oboval em vista superior, se projetando entre as tépalas.

Material examinado: BRASIL, Pará: Belém, Catú, Providência, 21/III/1916, fr., Ducke s/n (MG 16009). Castanhal, Campus do IFPA, 01¹8'02"S, 4757’03”W, 9/VI/2010, st., Leal 267 (RB). Curuça, Ilha do Mutucal, 7/IV/2007, fl. fr., Oliveira et al. 896 (holótipo, MG). Portel, Flona de Caxiua-

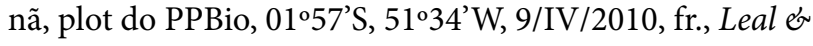
Koch 109 (MG, RB).

Asplundia altiscandens se distribui pela Amazônia brasileira, no Amazonas, nos arredores de Manaus, Amapá e Pará, próximo à Belém, no nordeste do estado e também na ilha do Marajó (Leal 2011). Habita as margens de rios e igarapés, áreas inundadas, baixios em áreas de floresta primária. Foi coletada com flores em abril, e com frutos de março a maio.

\section{Asplundia fanshawei (Maguire) Harling, Acta Horti} Berg. 17: 42. 1954.

Fig. 1

Hemiepífita, caule ca. $5 \mathrm{~m}$ compr., 1-2 cm diâm. (segundo Maguire 1948: 189). Folhas alterno-espiraladas, bipartidas, lâmina ca. $40 \mathrm{~cm}$ compr., partida até $65 \%$ do compr., sub 3-costada, costas laterais inconspícuas, aparentando ser 1-costada, cada segmento ca. $12 \mathrm{~cm}$ larg., oboval a oblanceolado, ápice acuminado, base decurrente, ca. 10 nervuras secundárias proeminentes na face abaxial; pecíolo ca. $35 \mathrm{~cm}$ compr., sulcado na região distal, alado e canaliculado na sua porção proximal; epiderme da base não variando em cor, não se desprendendo, com pontos marrons, bainha ca. $1 \mathrm{~cm}$ larg. Inflorescência não observada completamente, pedúnculo ca. $12 \mathrm{~cm}$ compr. Flores estaminadas assimétricas, ca. $2 \mathrm{~mm}$ compr., ca. $1 \mathrm{~mm}$ diâm., pedicelo excêntrico, receptáculo aplanado, perianto 4 lobos; estames ca. 25, mesmo tamanho, anteras globosas, ca. $1 \mathrm{x}$ $0,5 \mathrm{~mm}$, filete e conectivo inconspícuos. Flores pistiladas ca. $2 \times 2,5 \mathrm{~mm}$; tépalas ca. 1,5 mm larg., truncadas; estigma ca. $1 \mathrm{~mm}$ compr., lanceolado ou levemente obovado em vista superior, não se projetando entre as tépalas. Infrutescência não observada.

Material examinado: BRASIL, Pará: Viseu, Rio Piriá, V/1958, fl., Fróes 34297 (IAN).

Ocorre na Guiana, Suriname e no Peru (Brako \& Zarucchi 1993; Boggan et al. 1997; Mori et al. 1997; Funk et al. 2007). No Brasil é conhecida por apenas uma coleta realizada no nordeste paraense em 1950. Apesar das tentativas não foi possível encontrar a espécie na natureza. Floresce em maio.

\section{Asplundia glandulosa (Gleason) Harling, Acta Horti} Berg. 17: 42. 1954.

Fig. 2-6

Terrestre, às vezes escandente, altura desconhecida. Folhas alterno-espiraladas, bífidas, lâmina ca. $80 \mathrm{~cm}$ compr., partida cerca de $50 \%$ do compr., 3-costada, costas laterais percorrendo o meio da lâmina, até ca. $30 \mathrm{~cm}$, a partir desse ponto se tornando difusa, cada segmento ca. $12 \mathrm{~cm}$ larg., oblanceolado, ápice agudo, base decurrente, 10-15 nervuras secundárias proeminentes na face abaxial; 
pecíolo de tamanho desconhecido, alado na região distal, epiderme da bainha não se desprendendo, coloração uniforme, não brilhosa. Inflorescência axilar, pedúnculo ca. 15 cm compr.; espatas 3 , levemente cimbiformes, agudas, se distribuindo até $3 \mathrm{~cm}$ abaixo do espádice, a inferior ca. $7 \mathrm{x}$ $1,5 \mathrm{~cm}$, a superior ca. $4 \times 1 \mathrm{~cm}$, espádice cilíndrico, ca. 3,5 $\mathrm{x} 1,5 \mathrm{~cm}$. Flores estaminadas assimétricas, ca. $2,5 \times 2 \mathrm{~mm}$, pedicelo excêntrico, receptáculo aplanado, perianto 3-4 lobos portando glândula conspícua, anteras globosas, $0,5-0,6 \times 0,3 \mathrm{~mm}$, filete ca. $0,2 \mathrm{~mm}$ compr. Flores pistiladas ca. $3 \mathrm{~mm}$ diâm., tépalas inteiras, ca. $2 \times 2 \mathrm{~mm}$, truncadas, às vezes mais baixas que o estigma; estigma ca. $2 \mathrm{~mm}$ compr., elíptico em vista superior, se projetando entre as tépalas. Infrutescência não observada.

Material examinado: BRASIL, Pará: Rio Piriá, 18/ VIII/1958, fl., Fróes 34597 (IAN).

Asplundia glandulosa é rara e pouco amostrada em coleções de herbário. É restrita a porção norte da América do Sul ocorrendo na Guiana, Guiana Francesa, Suriname (Boggan et al. 1997; Funk et al. 2007) e na Amazônia Oriental brasileira, onde é conhecida por apenas uma coleta no Pará. Apesar das nossas tentativas, não foi possível encontrar esta espécie na natureza. Cresce em grandes moitas, preferencialmente em florestas úmidas, nas margens de rios e igarapés (Harling 1958). Segundo Harling (1958) floresce em abril, maio e agosto, e frutifica em junho.

Gleason (1929) descreveu Carludovica glandulosa (= Asplundia glandulosa) salientando as glândulas no perianto da flor estaminada como caráter diagnóstico para a espécie. Entretanto, a presença de glândulas no perianto é comum a todas as Carludovicoideae (Harling 1958). Asplundia glandulosa é semelhante a A. luetzelburgii Harling, mas esta não possui o pecíolo alado e os segmentos da lâmina foliar são sub3-costados e mais estreitos.

\section{Asplundia heteranthera Harling, Acta Horti Berg.} 18: 152. 1958.

Fig. 7-8

Hábito desconhecido, provavelmente hemiepífita; caule não observado; raízes grampiformes. Folhas espiraladas, bífidas; lâmina ca. $28 \mathrm{~cm}$ compr., partida até $65 \%$ do compr., 1-costada, cada segmento ca. $3,5 \mathrm{~cm}$ larg., linear-lanceolado, ápice acuminado, base atenuada, 5 a 6 nervuras secundárias proeminentes na face abaxial; pecíolo $12-14 \mathrm{~cm}$ compr., levemente canaliculado, bainha ca. $0,5 \mathrm{~cm}$ larg., epiderme da base não se desprendendo, coloração uniforme, não brilhosa. Inflorescência e flores não vistas. Infrutescência pêndula, pedúnculo ca. $6 \mathrm{~cm}$ compr., espatas 4, lanceoladas, cuspidadas, se distribuindo ao longo do pedúnculo, a mais inferior inserida próximo a base, a mais superior a $1,5 \mathrm{~cm}$ do espádice, as inferiores maiores que as superiores, 4-6 x 1,5-2 $\mathrm{cm}$, espádice cilíndrico, ca. 2 × 1,5 cm; bagas coalescentes, $2-3 \times 0,5 \mathrm{~mm}$; tépalas livres, triangulares, às vezes conatas na base, ca. 2 × $2 \mathrm{~mm}$; estigma ca. $2 \mathrm{~mm}$ compr., elíptico em vista superior, se projetando entre as tépalas.
Material examinado: BRASIL, Pará: Igarapé-açú, colônia do Prata, 24/IX/1903, fr., Huber 3831 (isótipo, MG).

A espécie ocorre na Guiana Francesa e no Suriname (Funk et al. 2007) e no Brasil, onde é conhecida somente pela coleção-tipo, oriunda do nordeste do Pará. Floresce em setembro.

Asplundia heteranthera é relacionada com A. moritziana e A. maximiliani, diferindo da primeira principalmente pelo número de espatas (de 5 a 6 ), e da última pela forma do receptáculo e tamanho das anteras.

\section{Asplundia latifrons (Drude) Harling, Acta Horti Berg. 17: 42.1954}

Fig. 9-11

Terrestre, às vezes escandente, 1,2-2 m alt.; quando terrestre caule curto; raízes não observadas. Folhas espiraladas, bífidas; lâmina $55-65 \mathrm{~cm}$ compr., partida até aproximadamente $65 \%$ do compr., 3 -costada, costas laterais correndo aproximadamente no meio do segmento, cada segmento de 14-16 cm larg., oval, ápice acuminado a agudo, base decurrente, ca. 16 nervuras secundárias proeminentes na face abaxial; pecíolo ca. $65 \mathrm{~cm}$ compr., alado até a metade do comprimento, fortemente canaliculado próximo a bainha e levemente em sua porção distal, epiderme na base do pecíolo amarela, quebradiça, brilhosa e dura, bainha não observada. Inflorescência não observada. Infrutescência axilar, pedúnculo $12-20 \mathrm{~cm}$; espatas 4, a julgar pelas cicatrizes, a mais inferior localizada próximo a região mediana do pedúnculo, as 3 superiores localizadas até $3 \mathrm{~cm}$ abaixo do espádice; espádice cilíndrico, 4-4,5 x 1,5 cm; bagas coalescentes, ca. 5 x 5-6 mm; tépalas conatas, truncadas, ca. $5 \mathrm{~mm}$ larg.; estigmas ca. $2 \mathrm{~mm}$ compr., ovais em vista superior, às vezes se projetando entre as tépalas.

Material examinado: BRASIL, Pará: Parauapebas, Serra dos Carajás, floresta próxima à bica do CIMCOP, 13/ III/1990, fr., Rocha \& Silva 743 (MG); Serra dos Carajás, "Azul" near camp at Serra Norte, 05'59'S, 50²8'W, 8-12/ XII/1981, fr., Daly et al. 1846 (MG).

Asplundia latifrons é conhecida apenas por três espécimes coletados na Amazônia brasileira (Pará e Amazonas). É provável que a espécie ocorra também em países do norte da América do Sul que fazem fronteira com o Brasil como Guiana, Guiana Francesa, Suriname e Venezuela. No Pará, ocorre na Serra dos Carajás, no sudeste do estado. Segundo dados de herbário A. latifrons ocorre em açaizais nativos das florestas de baixio da Amazônia, em solos bastante úmidos, próximos a pequenos igarapés e, às vezes, entre pequenos afloramentos rochosos no meio da vegetação. Frutifica nos meses de março, maio e dezembro; nenhum espécime em estágio florífero foi analisado.

Apresenta afinidades morfológicas com A. maguirei Harling e A. flavovaginata Harling. Da primeira difere pelo número de espatas, três em $A$. maguirei e quatro em $A$. latifrons, e pelos longos estiletes. De A. flavovaginata difere 

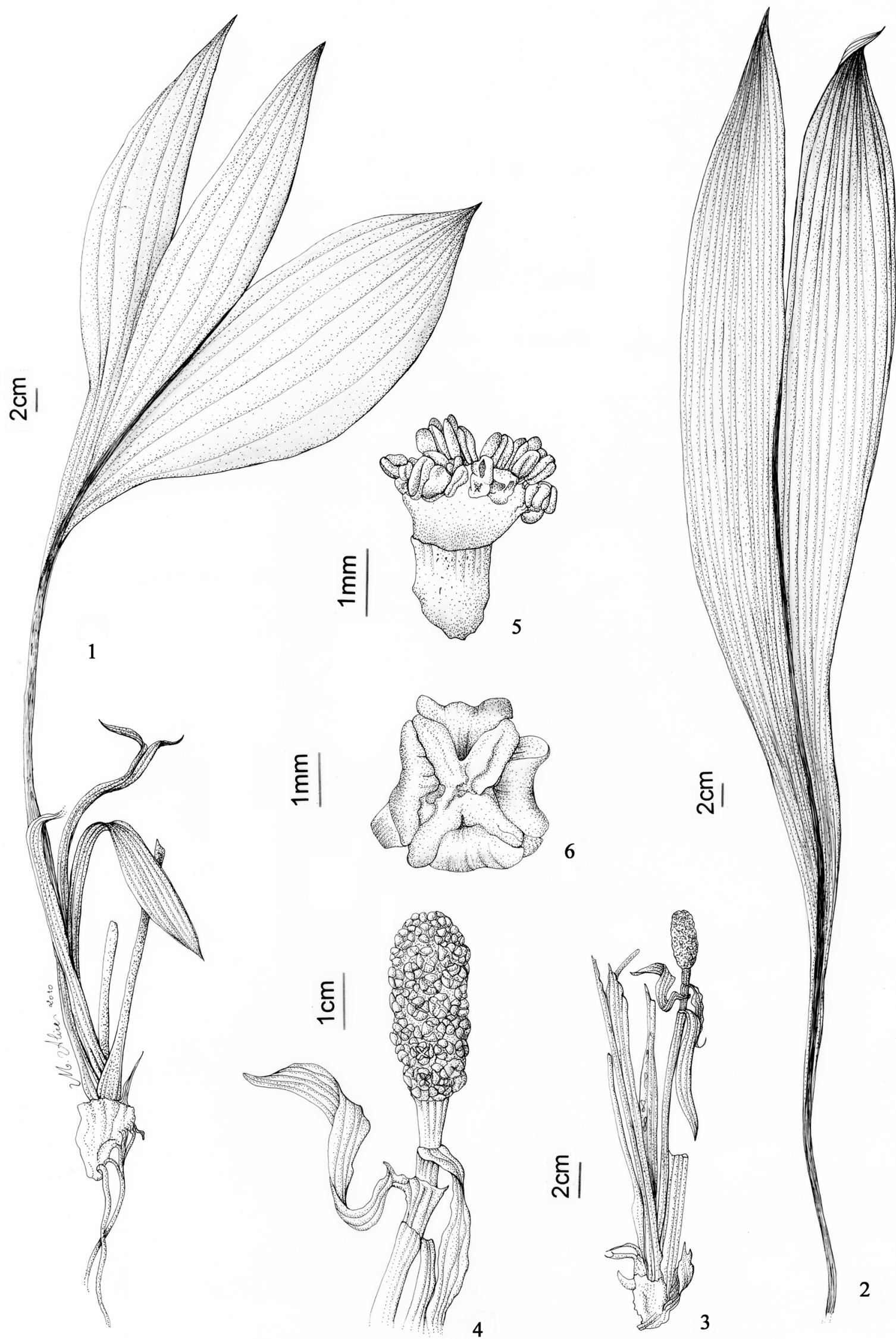

Figura 1-6. Asplundia fanshawei (Maguire) Harling: 1. Ramo. 2-6. A. glandulosa (Gleason) Harling: 2. folha; 3. Infrutescência; 4. Detalhe da infrutescência; 5. Vista da região adaxial da flor estaminada; 6. Vista superior da flor pistilada (1: Fróes 34297; 2-6: Fróes 34597). 


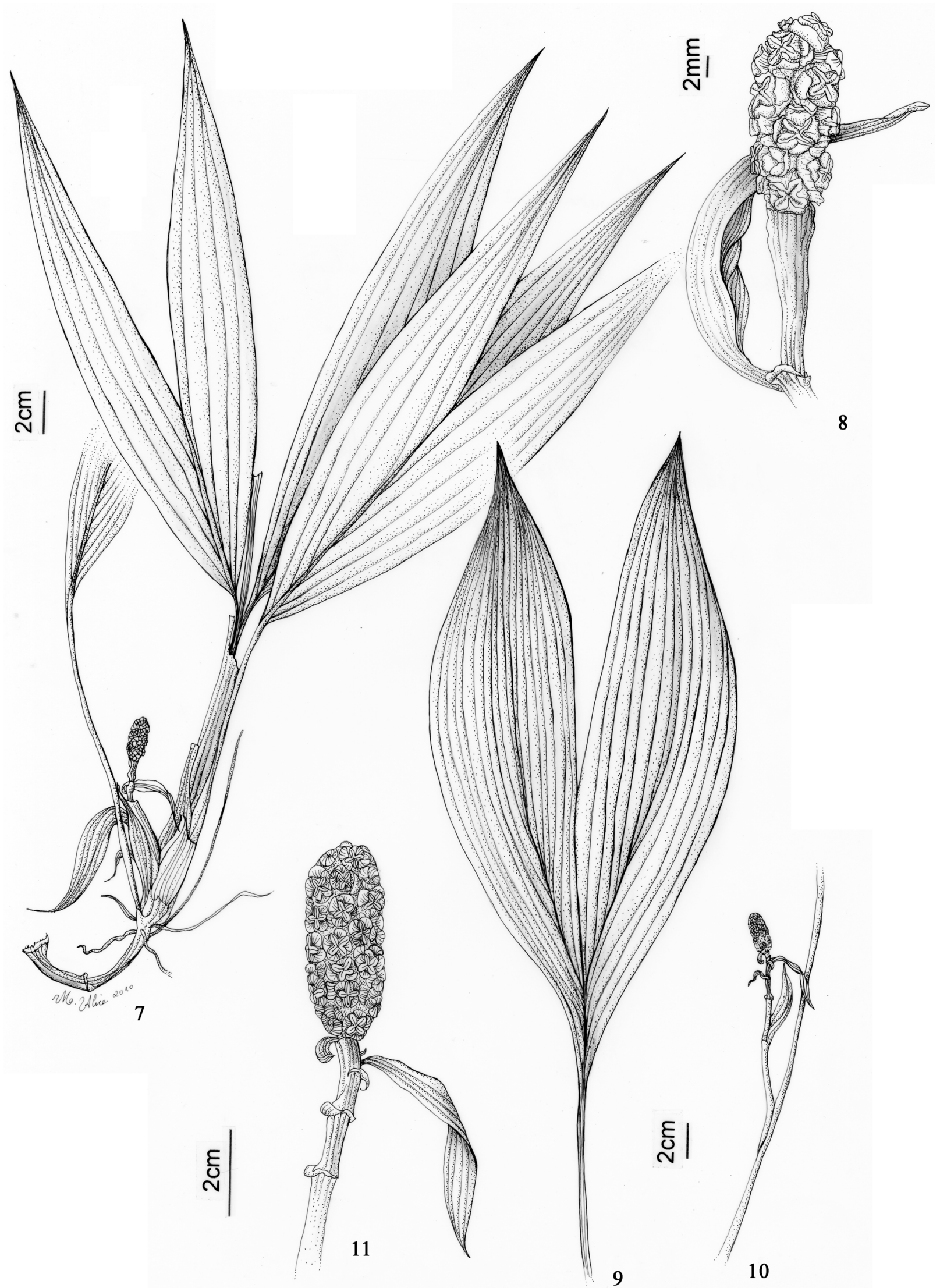

Figuras 7-11. Asplundia heteranthera Harling: 7. Ramo; 8. Detalhe da infrutescência. 9-11. A. latifrons (Drude) Harling: 9. Folha; 10. Ramo com infrutescência; 11. Detalhe da infrutescência (7-8: Huber 3831; 9-11: Daly 1846). 
por esta possuir a epiderme do pecíolo e do pedúnculo mais dura e brilhosa. O formato de suas grandes folhas aliado a seu hábito terrestre, distinguem facilmente A. latifrons das demais encontradas no Pará.

\section{Asplundia schizotepala Harling, Acta Horti Berg. 18: 155-156. 1958.}

Fig. $12-18$

Hemiepífita ca. $2 \mathrm{~m}$ alt.; caule 0,5-1 cm diâm. com cicatrizes foliares; raízes grampiformes. Folhas espiraladas, bífidas; lâmina $15-30 \mathrm{~cm}$ compr., partida de $50 \%$ a $60 \%$ do compr., 1-costada, segmentos 2,5-5 cm larg., linear-lanceolados, ápice acuminado, base decurrente, às vezes assimétrica, 5-7 nervuras secundárias evidentes na face abaxial; pecíolo 7-15 cm compr., canaliculado, bainha 0,5-1 cm larg., epiderme da base não se desprendendo, às vezes enegrecidas em material seco. Inflorescência axilar, pedúnculo $4-7 \mathrm{~cm}$ compr.; espatas 3 , a julgar pelas cicatrizes; espádice cilíndrico, às vezes globoso, ca. $1,5 \times 1 \mathrm{~cm}$. Flores estaminadas simétricas, ca. $2 \mathrm{~mm}$, pedicelo com pequena curvatura, receptáculo profundamente côncavo, lobos do perianto ca. 20 , ca. $0,5 \mathrm{~mm}$ compr.; estames $80-90$, anteras $0,6-1,5 \times 0,5 \mathrm{~mm}$, as da periferia menores que as do centro, filete $0,3-0,5 \mathrm{~mm}$ compr., às vezes ausente nos estames da periferia. Flores pistiladas conatas, ca. $4 \mathrm{~mm}$ diâm., tépalas livres, fimbriadas, cada segmento ca. $1 \mathrm{~mm}$ larg., filiformes, menores que o estigma; estigma ca. $1 \mathrm{~mm}$ compr., lateralmente linear em vista superior, transpassando as tépalas; estaminódios alaranjados, ca. $6 \mathrm{~cm}$ compr. Infrutescência pêndula, pedúnculo $4,5 \mathrm{~cm}$ compr., espádice cilíndrico, às vezes globoso, verdes, $2-3 \times 2 \mathrm{~cm}$.; bagas coalescentes, $5 \times 0,5-0,8 \mathrm{~mm}$ larg.; tépalas fimbriadas, lanceolados, três lóbulos filiformes, ca. $3 \times 1-2 \mathrm{~mm}$, estigmas ca. $2 \mathrm{~mm}$ compr., ovais em vista superior, raramente se projetando entre os estigmas.

Material examinado: BRASIL, Pará: Parauapebas, Serra dos Carajás, "Azul", near camp at Serra Norte, 0559'S, 50²8'W, 8-12.XII/1981, fr., Daly et al. 1845 (MG).

Material adicional examinado: BRASIL, Amazonas: Envira, norte BR 236 e ao leste do rio Envira, $08^{\circ} 07^{\prime} \mathrm{S}, 69^{\circ} 58^{\prime} \mathrm{W}$, 31/X/1987, fl., Araújo \& Ferreira 475 (MG, RB). Rondônia: Estrada Porto Velho-Cuiabá, km 283, 14/II/1983, fr., Bilby et al. 127 (INPA).

Ocorre no Equador e Peru (Harling 1958; Brako \& Zaruchi 1993). No Brasil pode ser encontrada no Acre, Amazonas, Rondônia e Pará. Segundo os dados de herbário, ocorre em áreas de baixio de florestas, próximo a cursos d'água e na margem de pequenos igarapés. Floresce no mês de março e frutifica de dezembro e fevereiro.

Segundo Harling (1958), A. schizotepala, juntamente com A. cuspidata Harling e A. parviflora Harling, fazem parte de um grupo de espécies caracterizadas pelas tépalas das flores pistiladas fimbriadas e pelos estigmas distintamente sulcados. Porém, A. cuspidata possui os segmentos foliares ovais, com ápice fortemente acumi- nado e segmentos mais largos, e A. parviflora possui flores menores.

7. Asplundia xiphophylla Harling, Acta Horti Berg. 18: 199-200, fig. 52b-d, t.27. 1958.

Fig. 19-23

Hemiepífita até $6 \mathrm{~m}$ alt.; caule ca. $1,5 \mathrm{~cm}$ diâm.; com raízes grampiformes, castanhas. Folhas alterno-espiraladas, bífidas; lâmina 45-65 cm compr., partida quase até a base, sub3-costada, costas laterais inconspícuas, cada segmento 3-7 cm larg., linear-lanceolados, ápice acuminado, base decurrente, 6 a 7 nervuras secundárias proeminentes na face abaxial; pecíolo $25-50 \mathrm{~cm}$ compr., levemente canaliculado, epiderme da bainha e região inferior do pecíolo, amarela a alaranjada com pontos castanhos, dura, brilhosa, quebradiça; bainha ca. $1,5 \mathrm{~cm}$ larg. Inflorescência axilar, pedúnculo ca. $8 \mathrm{~cm}$ compr.; espatas 4 , a inferior localizada aprox. na metade do pedúnculo, as superiores dispostas até $2 \mathrm{~cm}$ abaixo do espádice, lanceoladas, 3,5-6 x 1,5 cm. Flores estaminadas assimétricas, ca. $3 \times 2 \mathrm{~mm}$, pedicelo excêntrico, receptáculo aplanado; lobos do perianto 4 , estames ca. 30 , anteras filiformes aproximadamente o mesmo tamanho, 0,6-0,7 x $0,3 \mathrm{~mm}$, filete e conectivo inconspícuos. Flores pistiladas conatas, ca. $3 \mathrm{~mm}$ diâm., tépalas livres, triangulares a lanceoladas, recurvadas sobre os estigmas, ca. 2 × 1,5 mm; estigmas ca. 1,5-2 mm compr., largo-lanceolados em vista superior, às vezes se projetando entre as tépalas. Infrutescência pêndula, pedúnculo $7-20 \mathrm{~cm}$ compr., pendente; espádice cilíndrico, às vezes globoso, verde, 1,5-5 x 1-2,5 $\mathrm{cm}$; bagas coalescentes, ca. $5 \times 5 \mathrm{~mm}$; tépalas conatas até a metade, truncadas, ca. $4 \mathrm{~mm}$ compr., com uma pequena elevação na face adaxial; estigmas 1-2,5 mm compr., oval em vista superior, às vezes se projetando entre as tépalas.

Material selecionado: BRASIL, Pará: Tucuruí, área 4 das obras da UHT. Mata de Terra Firme, beira da picada, 17/XII/1979, fr., Silva et al. 446 (INPA, MG).

Asplundia xiphophylla ocorre na Colômbia, Peru e Venezuela (Harling 1958; Brako \& Zaruchi 1993; Funk et al. 2007). No Brasil a espécie é comum na Amazônia Ocidental com muitos espécimes coletados no Amazonas, Acre e Rondônia. No Pará é conhecida por apenas duas amostras coletadas no município de Tucuruí no sudeste do estado. De acordo com notas de coletores A. xiphophylla ocorre em matas úmidas nas beiras de picadas e na beira de igarapés. Floresce nos meses de fevereiro e julho e frutifica durante todo ano.

Asplundia xiphophylla é reconhecida pelas suas folhas longas e estreitas e pelo pecíolo com bainha alaranjada a amarela, dura, quebradiça e variegada com pontos castanhos. É vegetativamente muito semelhante a A. longicrura (Drude) Harling., porém difere na estrutura das flores pistiladas, principalmente pela forma dos estigmas. Enquanto em A. xiphophylla os estigmas são longos, aplanados e pontudos, em A. longicrura são curtos, convexos e truncados. 


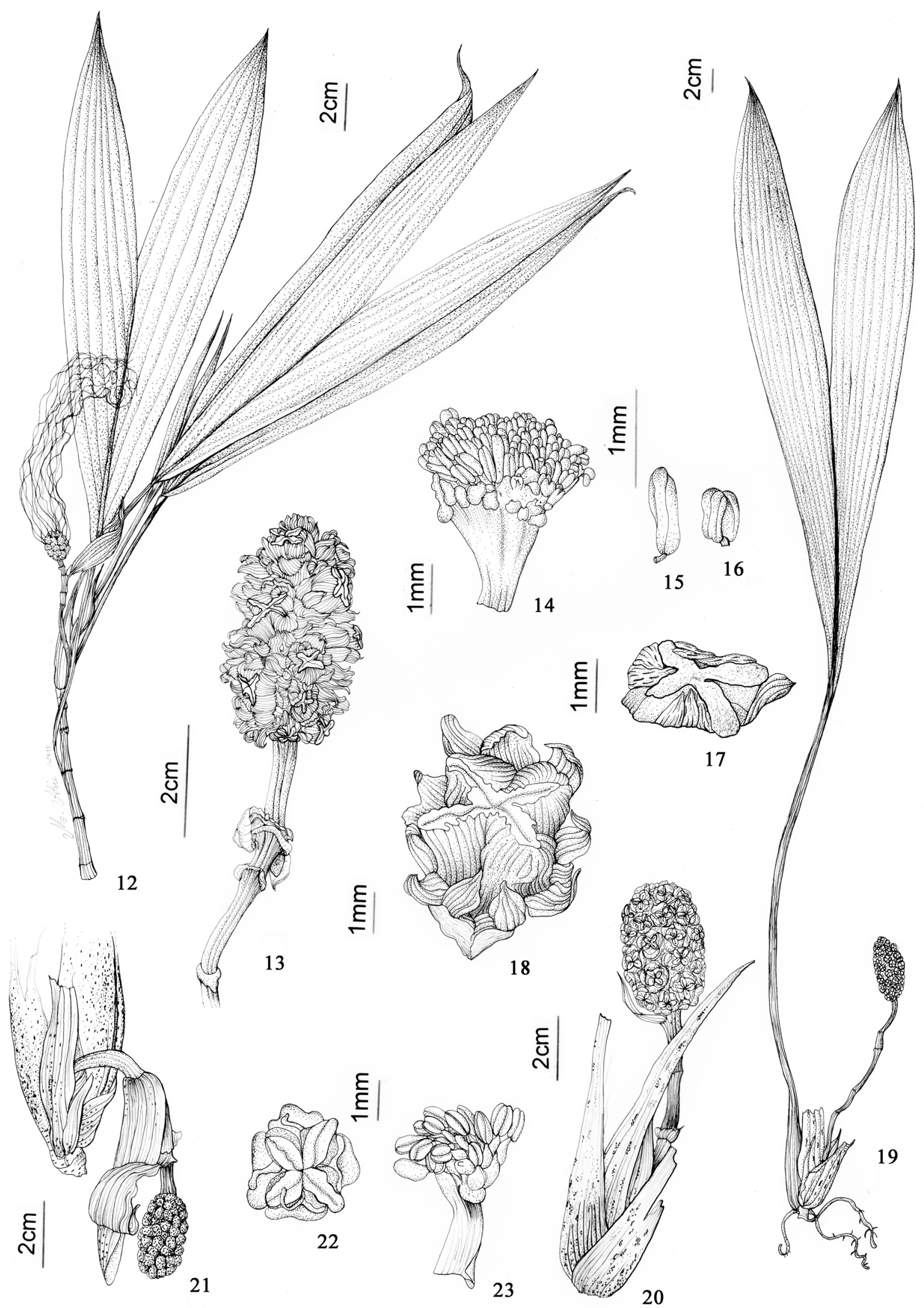

Figuras 12-23. Asplundia schizotepala Harling: 12. Ramo com inflorescência; 13. Infrutescência; 14. Flor estaminada; 15-16. Variação no tamanho dos estames; 17. Flor pistilada; 18. Baga. 19-23. A. xiphophylla Harling: 19. Ramo com infrutescência; 20. Infrutescência; 21. Inflorescência; 22. Flor pistilada, vista superior; 23. Flor estaminada, vista lateral. (12, 14-17: Araújo 475; 13, 18: Daly 1845; 19: Silva 446; 20: Prance 21407; 21-23: Silva 215). 
8. Cyclanthus bipartitus Poit. ex A. Rich., Dict. Class. Hist. Nat. 5: 222. 1824.

Fig. 24-28

Terrestre até 2,5 m alt.; muitas vezes crescendo em densas populações; caule rizomatoso, exsudato avermelhado ao corte do pecíolo ou do rizoma. Folhas espiraladas, partidas até a base, às vezes inteiras com uma linha de fissão na região mediana em plantas jovens, verde-escuras em plantas adultas e verde-claras em plantas jovens; lâmina $60-90 \mathrm{~cm}$ compr., 2-costada, segmentos 10-15 cm larg., linear-lanceolado a falcado, ápice agudo, base atenuada, nervuras principais bem evidentes, percorrendo cada segmento até o ápice; pecíolo cilíndrico, levemente canaliculado, verde-claro, 0,6-1,5 m compr.; bainha bem desenvolvida, amarela, $2-3 \mathrm{~cm}$ larg., envolvendo o rizoma. Inflorescência terminal, pedúnculo 25$70 \mathrm{~cm}$ compr., espatas 4, distribuídas na metade superior do pedúnculo, as inferiores maiores, as mais próximas do espádice diminuindo de tamanho, 5,5-17 x 2,5-4,5 cm, amarelas, lanceoladas, pouco cimbiformes, caducas; espádice cilíndrico, $2-6 \times 1,5-2,5 \mathrm{~cm}$. Flores estaminadas e pistiladas dispostas em anéis alternados, aclamídeas, flores do mesmo sexo totalmente conatas entre sí (exceto os estames e os estigmas); flores estaminadas com estames dispostos em verticilos, geralmente 4, fusionados pelo filete; flores pistiladas com anel possuindo uma cavidade ovariana comum; estaminódios consistindo de lamelas acanaladas com anteras estéreis. Infrutescência com pedúnculo ca. $80 \mathrm{~cm}$ compr.; espádice cilíndrico, parafusiforme, verde passando a amarelo, $5-10 \times 2-5 \mathrm{~cm}$; na maturidade se desfaz em discos, os ciclos pistilados do espádice se incham e se desprendem do espádice, liberando as sementes.

Material selecionado: BRASIL, Pará: Almeirim, Distrito de Monte Dourado, 0109'42”S, 52³7’35”W, 1/VI/2010, st., Leal \& Forzza 184 (RB). Belém, margem do Rio Guamá, 23/ II/1951, fl., Pires 3107 (IAN). Melgaço, Floresta Nacional de Caxiuanã, $01^{\circ} 43^{\prime} 38^{\prime \prime}$ ', 51 ${ }^{\circ} 27^{\prime} 19^{\prime \prime} \mathrm{W}, 10 / \mathrm{IV} / 2010$, st., Leal \& Koch 123 (RB). Itaituba, BR 163, km 1300, vicinity of igarapé José Preto, 23/XI/1977, fr., Prance et al. 25706 (MG).

Cyclanthus bipartitus se distribui por toda a América Central e norte da América do Sul. No Brasil ocorre em todos os estados da região Norte e Mato Grosso (Leal 2010). Habita preferencialmente florestas úmidas de baixio, crescendo em densas populações nas margens de pequenos igarapés, em áreas alagadas, podendo ocorrer também em áreas abertas ou florestas alteradas. Amostras com flores são provenientes de quase todos os meses do ano e espécimes em fruto foram observados em dois períodos, de outubro a fevereiro, e de maio a julho.

9. Evodianthus funifer (Poit.) Lindm., Bih. Kongl. Svenska Vetensk.-Akad. Handl. 26: 8. 1900.

Fig. 29-35

Hemiepífita até $6 \mathrm{~m}$ alt.; caule 1-3 cm diâm.; raízes grampiformes abundantes, castanhas. Folhas bífidas, pendentes, face adaxial verde-escura, face abaxial verde- -clara, espiraladas; lâminas 9-70-(90) cm compr., partidas até aproximadamente $75 \%$ da lâmina ou quase até a base, 1-costada, cada segmento 1,5-6,5 cm larg., linear-lanceolado, ápice agudo a acuminado, base decurrente, 5 a 8 nervuras secundárias proeminentes na face abaxial; com folhas inteiras, principalmente em ramos jovens, 6-15 x 5-7 cm; pecíolo 10-45 cm compr., canaliculado, bainha amarelada, 1-2 cm larg., epiderme se desprendendo. Inflorescência terminal, pedúnculo $10-15 \mathrm{~cm}$ compr., espatas 3 , cimbiformes, acuminadas, agrupadas logo abaixo do espádice, aproximadamente mesmo tamanho, 4,5-6 x 2 $\mathrm{cm}$, caducas, às vezes persistentes na infrutescência, cicatrizes bem evidentes no pedúnculo; espádice cilíndrico, às vezes globoso, $1-3 \times 1-2 \mathrm{~cm}$. Flores estaminadas simétricas, 3-4 × 2-3 mm, pedicelo com pequena curvatura, receptáculo côncavo; perianto em dois verticilos, 10-15 lobos em cada verticilo, lobos do verticilo externo menores, obtusos, com uma glândula na face adaxial, lobos do verticilo interno 1-2,5 x 0,3-0,4 mm, agudos dobrados sobre os estames; estames 10-15-(30), anteras do centro maiores que as da periferia, 0,6-1,2 x 0,2 $\mathrm{mm}$; filete e conectivo inconspícuos. Flores pistiladas livres, 3-5 mm diâm., tépalas inteiras, livres, triangulares, agudas, ca. $4 \times 3 \mathrm{~mm}$, curvadas sobre os estigmas; estaminódios alaranjados até $10 \mathrm{~cm}$ compr.; estigma lateralmente comprimido, 1-3 mm compr., linear em vista superior. Infrutescência pêndula, pedúnculo 10$25 \mathrm{~cm}$ compr., verde-clara quando imatura, esbranquiçada na maturidade; espádice cilíndrico, raro globoso, 1,5-4,5 x $1-2,5 \mathrm{~cm}$; bagas livres, $0,5-1 \times 0,5-0,8 \mathrm{~cm}$; tépalas conatas na base ou até a metade de seu comprimento, oblongas, acuminadas, recurvadas sobre os estigmas, 3,5-6 x 2,5-3,5 $\mathrm{mm}$; estigma 1-1,5 cm compr., lateralmente comprimido em vista superior, ligeiramente pontudo, filiforme a lanceolado, nunca se projetando até as tépalas.

Material selecionado: BRASIL, Pará: Altamira, Belo Monte, rio Xingu, X-XII/2007, fl. fr., Salomão 1103 (MG). Anajás, opposite town of Anajás on rio Anajás, 31/X/1984, fr., Sobel et al. 4945 (MG). Barcarena, área que será suprimida para a implantação da Companhia de Alumina do Pará, próximo ao trevo do peteca, $22 / \mathrm{X} / 2008$, fr., Leal $s / n$ (RB 499483, MG). Belém, on lands of Instituto Agronômico do Norte, 19/I/1944, fl. fr., Silva 46 (IAN). Benevides, rodovia Benevides-Mosqueiro, 14/VIII/1965, fl., Vieira 1 (MG). Bragança, E.F. Bragança, sítio Rettelbush, 30/IX/1962, fl. fr., Cavalcante \& Sioli 977 (MG). Breves, Jupatituba, VIII/1985, fl., Huber 18 (MG). Capanema, road BR 22, vicinity of Cachoeira, km 96, 29/X/1965, fr., Prance \& Pennington 1786 (IAN, K). Castanhal, estrada para Terra Alta km 25, ramal a direita, fazenda Cauã, 0103'59”S, 4752'03”'W, 24/II/2010, fl., Leal \& Campos 91 (MG, RB). Itaituba, entrando $3 \mathrm{~km}$ a margem direita do rio Tapajós, próximo a comunidade Jatobá, 9/IX/2008, bt., Leal s/n (RB 499482, GB, MG). Marituba, Granja Imperial, 30/VIII/1959, fl. fr., Engler 1137 (MG). Melgaço, Flona de Caxiuanã, 01 $42^{\circ}$ 'S, 51⒊ $31^{\prime} \mathrm{W}, 10 /$ IV/2010, fr., Leal \& Koch 116 (MG, RB). Óbidos, mata ao 


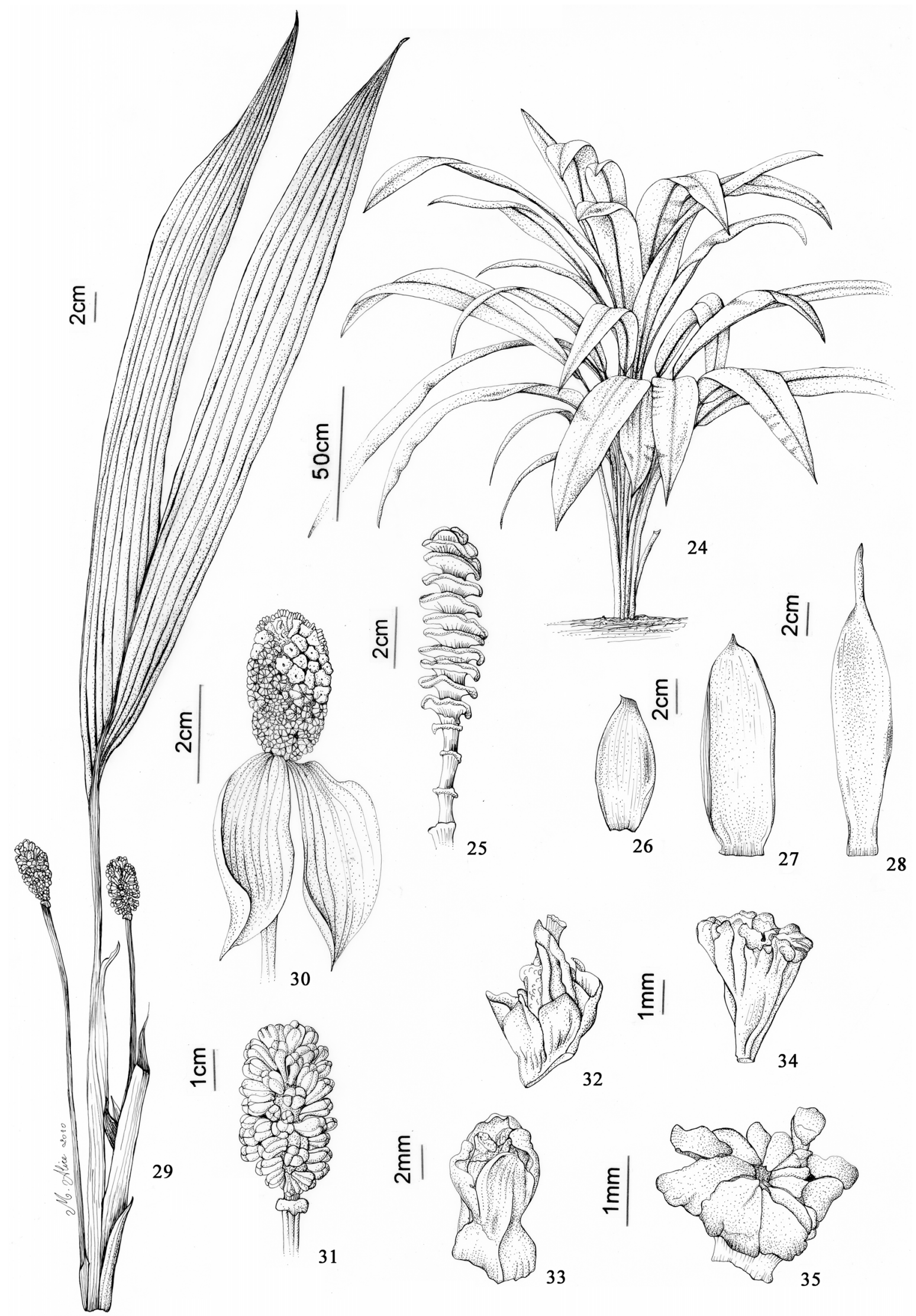

Figuras 24-35. Cyclanthus bipartitus Poit. ex A. Rich.: 24. Hábito; 25. Infrutescência; 26, 27, 28. Diferentes formas e tamanhos das espatas. Evodianthus funifer (Poit.) Lindm.: 29. Ramo com infrutescência; 30. Inflorescência; 31. Infrutescência; 32. Flor pistilada, vista lateral; 33. Baga; 34. Flor estaminada, vista lateral; 35. Flor estaminada, vista superior (24: Leal 184; 25-28: Cavalcante 1001; 29, 31, 33: Prance 1788; 30, 32, 34, 35: Ribeiro 152). 
norte do rio Curuçambá, 27/XII/1913, fr., Ducke s/n (MG 15267). Ourém, 2/XII/1903, st., Rodrigues s/n (MG 4032). Portel, Flona de Caxiuanã, plot do PPBio, 015ㄱ'S, 51 ${ }^{\circ} 34^{\prime} \mathrm{W}$, 9/IV/2010, fr., Leal \& Koch 101 (GB, MG, RB). Vigia, Vila Santo Expedito, 0 $0^{\circ} 57^{\prime} 05^{\prime}$ 'S, 48 $04^{\prime} 58^{\prime \prime} \mathrm{W}, 10 / \mathrm{XII} / 2009$, fr., Fraga et al. 2819 (MG, RB). Viseu, Rio Piriá, 30/IV/1958, fr., Fróes 34258 (IAN).

Evodianthus funifer tem como limite norte de distribuição a Costa Rica, ocorrendo também no Panamá e nas ilhas de Trinidad e Tobago (Harling 1958). A espécie é amplamente distribuída na América do Sul, sendo citada em diversos checklists e tratamentos taxonômicos (e.g. Harling 1973; Boggan et al. 1997; Funk et al. 2007). No Brasil possui uma distribuição disjunta, ocorrendo por toda a Amazônia e na Floresta Atlântica, do sul da Bahia ao norte do Espírito Santo (Leitman \& Leal 2009; Leal 2010). No Pará ocorre em Belém e região metropolitana e também é comum no nordeste paraense, se estendendo até o Maranhão. Ocorre também no Baixo Amazonas e no sudoeste do estado, na região dos rios Tapajós e Xingu. Seu habitat preferencial são áreas de baixio de florestas ombrófilas, próximo a cursos d'água. Entretanto, também é comum encontrar a espécie em áreas perturbadas em recomposição. Floresce de dezembro a janeiro e de julho a outubro. Exemplares em fruto foram coletados em quase todos os meses do ano, com exceção de junho e julho.

Harling (1958) propôs quatro subespécies em Evodianthus funifer, baseando-se principalmente em variações nas medidas e profundidade da partição das folhas e na persistência das espatas. Os caracteres adotados por este autor para distinção das subespécies são superficiais e pouco consistentes. Diante disso, nesse trabalho a subdivisão da espécie não foi considerada, procedimento também adotado por Hammel (2003) e Gomes e Mello-Silva (2006).

10. Ludovia lancifolia Brongn., Ann. Sci. Nat., Bot., sér. 4 : 362-364. 1861.

Fig. 36-37

Epífita até $6 \mathrm{~m}$ alt. no forófito, às vezes terrestre, nesse caso rizoma bem desenvolvido, raízes grampiformes quando epífita. Folhas inteiras, coriáceas, brilhantes, dísticas, 80-110 cm compr., 7-10 cm larg., 1-costadas, nervura conspícua, percorrendo toda a extensão da lâmina, oblanceoladas a espatuladas, ápice agudo, crenado, base decurrente; pecíolo $25-40 \mathrm{~cm}$ compr., levemente alado em sua região distal, bainha variando entre $2-3 \mathrm{~cm}$ larg. Inflorescência axilar, pedúnculo $4-5 \mathrm{~cm}$ compr., cilíndrica, ca. $2,5 \times 1 \mathrm{~cm}$; 3 espatas, nunca agrupadas, a mais inferior aproximadamente na metade do pedúnculo, lanceoladas, agudas, esverdeadas, a mais inferior ca. $5 \times 2 \mathrm{~cm}$, não envolvendo o espádice, a mais próxima do espádice 6-7 x $3 \mathrm{~cm}$. Flores estaminadas simétricas, $3 \times 4 \mathrm{~mm}$, subsésseis, receptáculo côncavo, perianto ca. 20 lobos, ca. 1 x 0,3 mm, acuminado, com glândulas conspícuas; estames 30-40, variando em tamanho, anteras dos estames do centro ca. $1,5 \times 0,3 \mathrm{~mm}$, filiformes, as periféricas ca. 0,7 x 0,2-0,4 mm, globosas, com bulbo basal mais desenvolvido, filetes e conectivos inconspícuos. Flores pistiladas conatas, $5 \mathrm{~mm}$ diâm., tépalas muito reduzidas, estigmas se projetando entre as tépalas, achatados lateralmente, lanceolados em vista superior; estaminódios $3-4 \mathrm{~cm}$ compr., esbranquiçados. Infrutescência ereta, pedúnculo 5-8 cm compr.; espádice cilíndrico, 4,5-6 x $2 \mathrm{~cm}$, bagas 1,5-2 $\mathrm{cm}$, coalescentes; tépalas inconspícuas, estigma alongado, lanceolado em vista superior.

Material examinado: BRASIL, Pará: Oriximiná, rio Mapuera, ca.10 km up river from Cachoeira Porteira, 30/ VI/1980, fr., Davidson \& Martinelli 10601 (INPA). Viseu, rio Piriá, V/1958, fr., Fróes 34048 (IAN).

Ludovia lancifolia se distribui pela Colômbia, Peru, Venezuela, Guiana, Guiana Francesa e Suriname. No Brasil, ocorre exclusivamente na Amazônia, em quase todos os estados da região norte e no Maranhão (Leal 2010). Segundo Harling (1958), a espécie cresce ao longo de pequenos cursos d'água em florestas ombrófilas, sendo observada sobre troncos ou afloramentos rochosos próximos a locais úmidos. Floresce em abril, agosto e outubro e frutifica durante quase todos os meses do ano.

Ludovia possui três espécies: L. lancifolia, L. integrifolia (Woodson) Harling e L. bierhorstii G.J. Wilder, sendo a primeira facilmente reconhecida pelas grandes folhas em forma de lança com ápice crenado. Outro nome encontrado em herbários para L. lancifolia é L. crenifolia Drude, que juntamente com Carludovica disthica Neumann foram sinonimizadas por Harling (1958).

\section{Thoracocarpus bissectus (Vell.) Harling, Acta Horti} Berg. 18: 255. 1958.

Fig. 38-45

Liana até $30 \mathrm{~m}$ compr. no forófito; caule 1-2-(4) cm diâm., anelado devido à presença de cicatrizes foliares, ramificando em sua porção terminal; raízes grampiformes, castanhas. Folhas espiraladas, bífidas, verde-escuras, brilhantes, lâmina 20-30-(40) cm compr., partida de 50\% a $65 \%$ do compr., 1 -costadas, cada segmento $2,5-4 \mathrm{~cm}$ larg., lanceolados, ápice acuminado, base atenuada e levemente assimétrica, 4 a 6 nervuras secundárias evidentes; com folhas inteiras em alguns indivíduos, nesse caso lanceoladas, 6-20 x 4-6 cm; pecíolo 6-15 cm compr., canaliculado, bainha 1-2 cm larg., epiderme com pontos castanhos, se desprendendo na base. Inflorescência axilar, pedúnculo 3-8 cm compr.; espatas 3 a 8 , a julgar pelas cicatrizes, cimbiformes, ápice acuminado, distribuídas ao longo do pedúnculo, as localizadas logo abaixo do espádice maiores, ca. $5 \times 3-4 \mathrm{~cm}$, as mais distantes do espádice diminuindo em tamanho, ca. 3 $\mathrm{x} 1 \mathrm{~cm}$, caducas ou às vezes persistente em estágio de fruto, cicatrizes bem evidentes no pedúnculo; espádice cilíndrico, às vezes globoso, $2-3 \times 1,5 \mathrm{~cm}$. Flores estaminadas simétricas, 6-10 x 4-6 $\mathrm{mm}$, pedicelo com uma pequena curvatura, receptáculo côncavo; 9-10 lobos do perianto, agudos, ca. 3 $\mathrm{x} 1 \mathrm{~mm}$, estames $30-45-(60)$, anteras $0,8-2 \times 0,2-0,5 \mathrm{~mm}$, as 


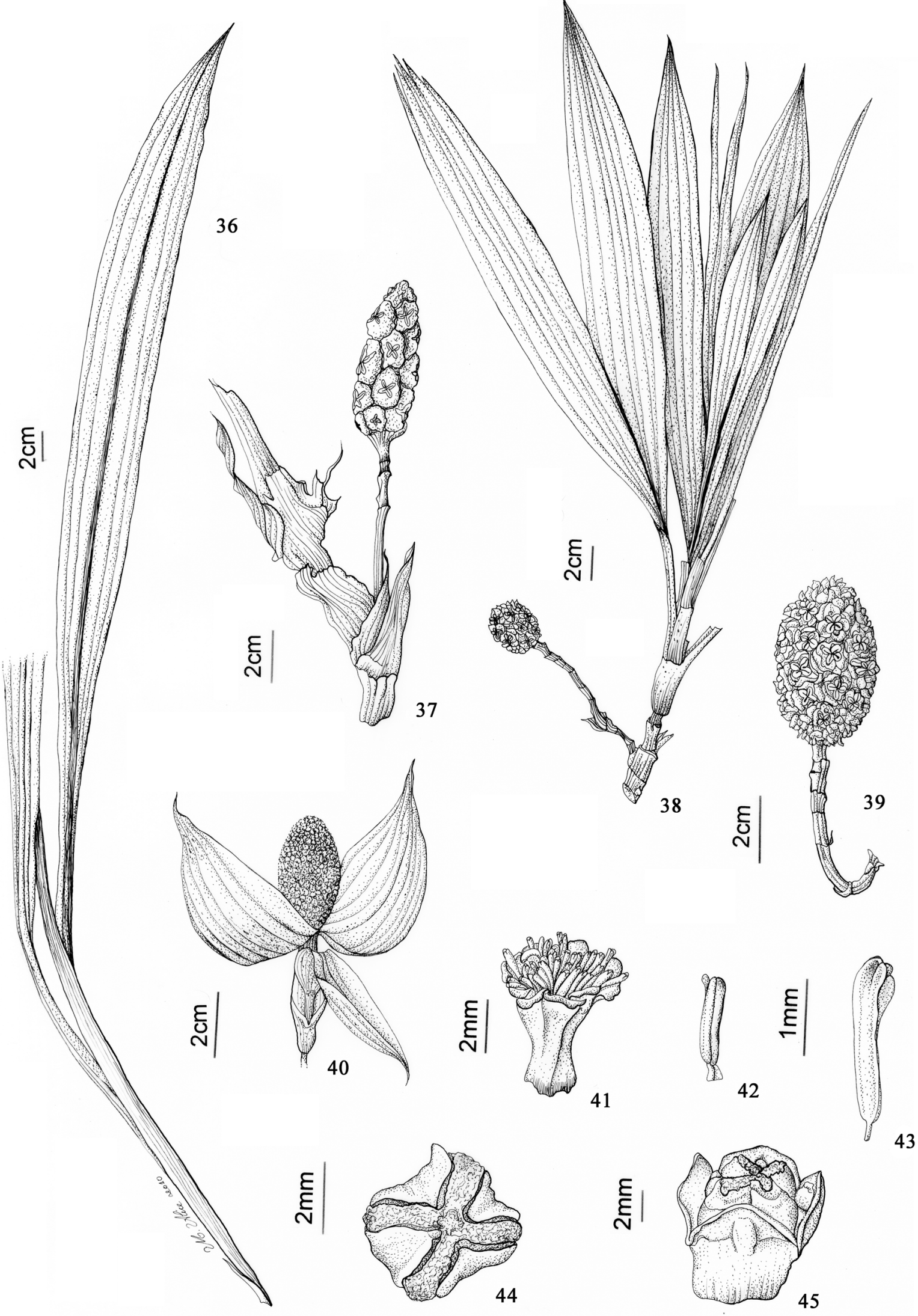

Figuras 36-45. Ludovia lancifolia Brongn.: 36. Folha; 37. Infrutescência. Thoracocarpus bissectus (Vell.) Harling. 38. Ramo com infrutescência; 39. Infrutescência; 40. Inflorescência; 41. Flor estaminada, vista lateral; 42, 43. Variação no tamanho dos estames; 44. Flor pistilada, vista superior; 45 . Baga (36- 37: Fróes 34348; 38-39: Prance 30226 ; 40-45: Silva 1399). 
anteras do centro do receptáculo maiores que as da periferia, creme, as vezes sésseis; filetes ca. $0,3 \mathrm{~mm}$ compr.; conectivo não observado. Flores pistiladas conatas, ca. $5 \mathrm{~mm}$ diâm.; tépalas inteiras, conatas na base, ca. $4 \times 3 \mathrm{~mm}$, agudas; estaminódios esbranquiçados ca. $6 \mathrm{~cm}$ compr., alaranjados; estigmas 1-2 mm compr., aplanados, transpassando as tépalas. Infrutescência pêndula, pedúnculo $7-17 \mathrm{~cm}$ compr.; espádice cilíndrico, raro esférico, verde-escuro, lustroso em material seco, 2,5-7 x 1,5-2,5 cm; bagas $1 \times 0,8-1,5 \mathrm{~cm}$, tépalas $8 \times 6 \mathrm{~mm}$, conatas na base, acuminadas, ápice recurvado, às vezes triangular, margem revoluta, protuberância na parte mediana da face adaxial, cicatrizes dos estaminódios evidentes; estigma 1,5-3 mm compr., lanceolado em vista superior, compresso lateralmente, às vezes se projetando entre as tépalas.

Material selecionado: BRASIL. Pará: Almeirim, Distrito de Monte Dourado, 12/XI/1968, fl., Silva 1399 (IAN). Anajás, rio Anajás, 2/XI/1987, fr., Rabelo et al. 3721 (INPA). Belém, on lands of Instituto Agronômico do Norte, 3/VII/1944, fl. fr., Silva 280 (IAN). Bragança, colônia Augusto Montenegro, 18/IX/1958, st., Fróes 34639 (IAN). Castanhal, campus do IFPA, $01^{\circ} 18^{\prime} 02^{\prime \prime}$, $47^{\circ} 57^{\prime} 03^{\prime \prime} \mathrm{W}, 9 / \mathrm{VI} / 2010$, st., Leal 265 (RB). Itaituba, estrada Santarém-Cuiabá, BR 163, entre os $\mathrm{km} 877$ a $876,08^{\circ} 45^{\prime}$ S, 545ㄷ' W, 7/V/1983, fl., Amaral et al. 1202 (INPA, MG). Marabá, Carajás, Serra Norte, km 7 da estrada de ferro Carajás, 12/VIII/1982, fr., Maciel et al. 802 (INPA, MG). Melgaço, Flona de Caxiuanã, estação científica Ferreira Pena, 01 ${ }^{\circ} 42^{\prime}$ S, 513ㄴ'W, 10/IV/2010, fr., Leal \& Koch 117 (RB). Mojú, estação experimental da Embrapa Amazônia Oriental, 22/IV/2004, fr., Nascimento et al. 365 (IAN). Oriximiná, Porto Trombetas, 1994, fl. fr., Evandro e Knowles 1232 (INPA). Peixe-boi, Vila do Ananim, fazenda da Sra. Catarina, 23/XI/1999, fr., Oliveira et al. 232 (MG). Santarém, Currupirú, localidade Gato, 22/VIII/1954, fl., Fróes 31043 (IAN). Santarém Novo, Reserva Extrativista Marinha Xocoaré-Mato Grosso, 23/VI/2005, st., Rocha et al. 241 (MG). Tucuruí, área de desmatamento, PA-149, ramal da massa falida, 16/IX/1983, fr., Ramos 843 (INPA). Viseu, localidade do Andirobal, $01^{\circ} 13^{\prime} 26^{\prime \prime}$, $46^{\circ} 17^{\prime} 32^{\prime \prime} \mathrm{W}$, 28/V/2010, st., Leal 142 (RB).

Thoracocarpus bissectus possui ampla distribuição geográfica, tendo como limite norte de ocorrência a Costa Rica. Na América do Sul, é citada em vários checklists e tratamentos taxonômicos (e.g. Harling 1973; Boggan et al. 1997; Funk et al. 2007). No Brasil a espécie tem uma distribuição disjunta, ocorrendo por toda a Amazônia e Floresta Atlântica, de Pernambuco até São Paulo, sendo este o seu limite sul (Gomes \& Giulietti 2003; Leal 2010). Ocorre, preferencialmente, em florestas ombrófilas maduras, em áreas de baixio, próximo a cursos d'água. Entretanto, ocasionalmente, pode ser encontrada em florestas secundárias nos estágios iniciais de recomposição. Floresce de abril a agosto e dezembro. Frutifica em todos os meses do ano.

O grande polimorfismo de T. bissectus, especialmente no tamanho das folhas e do caule e no tamanho e forma das brácteas, aliado a sua ampla distribuição geográfica, provocaram a publicação de vários nomes para essa espécie. Apesar desta grande variação morfológica a espécie é facilmente reconhecida pelo caule anelado, grande número de espatas e pelo seu fruto lustroso, que em material seco aparenta estar envernizado.

\section{Conclusão}

Foi registrada a ocorrência de 11 espécies de Cyclanthaceae no Pará, o que corresponde a aproximadamente $1 / 3$ da diversidade da família no Brasil. Asplundia schizotepala se trata de um novo registro para o estado. Uma nova espécie foi reconhecida com base no presente estudo (Leal 2011). Asplundia fanshawei, A. glandulosa e A. heteranthera são registradas no Brasil por apenas um espécime, apesar dos esforços de coleta. Cyclanthus bipartitus, Evodianthus funifer e Thoracocarpus bissectus apresentam ampla distribuição, ocorrendo praticamente por toda a faixa de distribuição geográfica da família. Asplundia latifrons e A. altiscandens são exclusivamente brasileiras, ocorrendo no Amazonas e Pará. O noroeste do estado, que corresponde à mesoregião do baixo Amazonas, compreende uma grande lacuna no conhecimento da flora amazônica, sendo provavelmente a região com menor índice de coletas. A proximidade dessa região com um dos centros de diversidade de Cyclanthaceae, aliado à escassez de registros provenientes dessa área, indica que o número de espécies para o estado e para o Brasil pode ser maior.

\section{Agradecimentos}

Este trabalho é parte da dissertação do primeiro autor desenvolvida no Jardim Botânico do Rio de Janeiro. À CAPES, pela concessão da bolsa de Mestrado; aos curadores dos herbários IAN, INPA, MG pelo auxílio durante a visita e empréstimo de espécimes. A segunda autora agradece ao CNPq e à FAPERJ, pela concessão de bolsa de produtividade em pesquisa e pelo auxílio Jovem Cientista do Estado do Rio de Janeiro, respectivamente.

\section{Referências bibliográficas}

APG III. 2009. An update of the Angiosperm Phylogeny Group classification for the orders and families of flowering plants: APG III. Botanical Journal of the Linnean Society 161: 105-121.

Boggan, J.; Funk, V.; Kelloff, C.; Hoff, M.; Cremers, G. \& Feuillet, C. 1997. Checklist of the plants of the Guianas (Guyana, Surinam, French Guiana). $2^{\text {nd }}$ Edition. Biological Diversity of the Guianas Program, Department of Botany, National Museum of Natural History, Smithsonian Institution, Washington, D.C.

Brako, L. \& Zarucchi, J.L. 1993. Catalogue of the Flowering Plants and Gymnosperms of Peru/Catálogo de las Angiospermas y Gimnospermas del Perú. Monographs in Systematic Botany from the Missouri Botanical Garden 45: 1-1286.

Drude, O. 1881. Cyclanthaceae. Pp. 226-250. In: Martius, C.F.P. \& Eichler, A. (Eds.). Flora Brasiliensis. Vol. 3, parte 2. Frid. Fleischer, Leipzig. 
Ellis, B.; Daly, D.C.; Hickey, L.J.; Johnson, K.R.; Mitchell, J.D.; Wilf, P. \& Wing, S.L. 2009. Manual of leaf architecture. Cornell University Press/New York Botanical Garden Press. New York.

Eriksson, R. 1995. The genus Sphaeradenia (Cyclanthaceae). Opera Botanica 126: 1-106.

Funk, V.; Hollowell, T.; Berry, P.; Kelloff, C.; \& Alexander, S. N. 2007. Checklist of the Plants of the Guiana Shield (Venezuela: Amazonas, Bolivar, Delta Amacuro; Guyana, Surinam, French Guiana). Contributions from the United States National Herbarium 55: 1-584.

Gleason, H.A. 1929. Studies on the flora of sorthern South America-XI. New or noteworthy Monocotyledons from British Guiana. Bulletin of the Torrey Botanical Club 56: 1-23.

Gomes, F.P. \& Giulietti, A.M. 2003. Cyclanthaceae. Pp. 67-69. In: Wanderley, M.G.L; Sheperd, G.J.; Giulietti, A.M. \& Melhem, T.S. (Eds.). Flora fanerogâmica do estado de São Paulo. Vol. 3. Ed. Rima, FAPESP, São Paulo.

Gomes, F.P. \& Mello-Silva, R. 2006. Flora da Reserva Ducke, Amazonas, Brasil: Cyclanthaceae. Rodriguésia 57: 159-170.

Hammel, B. 2003. Cyclanthaceae. In: Hammel, B. E.; Grayum, M. H.; Herrera, C. \& Zamora N. (Eds.). Manual de Plantas de Costa Rica. Vol. II.Gimnospermas y Monocotiledóneas (Agavaceae-Musaceae). Monographs in Systematic Botany from the Missouri Botanical Garden 92: 424-455.

Harling, G. 1958. Monograph of the Cyclanthaceae. Acta Horti Bergiani 18: $1-428$.

Harling, G. 1973. 216. Cyclanthaceae. In: Harling, G. \& Sparre, B. (Eds.). Flora do Ecuador 1: 1-48.

Harling, G. \& R. Eriksson. 1998. Cyclanthaceae. Pp. 471-486. In: Steyermark, J.A.; Berry, P.E. \& Holst B.K. (Eds.). Flora of the Venezuelan Guayana, Vol. 4. Caesalpiniaceae-Ericaceae. Missouri Botanical Garden Press, St. Louis.

Leal, E.S. 2010. Cyclanthaceae. Pp. 902-903. In: Forzza, R.C. et al. (Eds.). Catálogo de plantas e fungos do Brasil. Andrea Jakobsson Estúdio/ Jardim Botânico do Rio de Janeiro, Rio de Janeiro.

Leal, E.S. 2011. Asplundia altiscandens sp. nov. (Cyclanthaceae) from the Brazilian Amazon. Nordic Journal of Botany 29: 687-690.

Leitmam, P. \& Leal, E.S. 2009. Cyclanthaceae. Pp. 231. In: Stehmann, J.R.; Forzza, R.C.; Salino, A.; Sobral, M.; Costa, D.P. \& Kamino, L.H.Y. (Eds.). Plantas da Floresta Atlântica. Jardim Botânico do Rio de Janeiro, Rio de Janeiro.

Mori, S.A. 1997. Cyclanthaceae. In: Mori, S.A.; Cremers, G.; Gracie, C.; Granville, J.J.; Hoff, M. \& Mitchell, J.D. (eds.). Guide to the vascular plants of central French Guiana: Part 1. Pteridophytes, Gymnosperms, and Monocotyledons. Memoirs of the New York Botanical Garden 76: 244-249.

Stearn, W.T. 1983. Botanical Latin, $3^{\text {rd }}$ Edition. David \& Charles. London.

Thiers, B. 2011. Index Herbariorum: A global directory of public herbaria and associated staff. New York Botanical Garden's Virtual Herbarium. http://sweetgum.nybg.org/ih/ (Acesso em 27/07/2011).

\section{Apêndice 1 - Lista de exsicatas}

Acevedo, P. 14715 (7), 14783 (6). Aguiar, I.J. INPA 178468 (7). Albuquerque, B. 890 (9). Amaral, D.D. 231 (9). Amaral, I.L. 120 (9), 1202 (11), 1731 (9), 2783 (10), 2863 (8). Anderson, A.B. 347 (10). Andersson, L.A. 1746 (10), 1753 (10), 1845(8). Araújo, A.P. 475 (6). Archer, W.A. 7826 (9), 7896 (9). Baker. 120 (9). Bastos, M. 2265 (9). Beck, H.T. 162 (9), 267 (9). Berg, C.C. P18154 (11), P19621 (9), P19843 (8), P19921 (9). Bilby, R. 127 (6). Carvalho, F.A. 467 (7). Castilho, C.V. 938 (11). Cavalcante, P. 638 (8), 977 (9), 1001 (8), MG 31360 (10). Chagas, J. INPA 1749 (8), INPA 3684 (10). Coelho, D. 27D (8), 713 (8). Costa, M.A.S. 97 (8), 724 (9). Cowan,
R.S. 38134 (10). Croat, T.B. 85064 (9), 85345 (11), 85771 (8). Daly, D.C. 1845 (6), 1846 (5), 4042 (11), 4396 (8), 7647 (11), 8080 (11), 9991 (11). Davidson, C. 10601 (10). Duarte, A.P. 7062 (9). Ducke, A. 6845 (8), MG 15267 (9), MG 16009 (1), RB 25463 (8), RB 25468 (8). Emmerich, M. 763 (9). Egler, W.A. 164 (9), 1137 (9). Evandro. 1232 (11). Ferreira, C.A.C. 532 (11), 3469 (9), 7275 (11), 8599 (9), 9943 (8). Filardi, F.L.R. 772b (9). Fontana, A.P. 2530 (9). Forzza, R.C. 5383 (11). Fraga, C.N. 2819 (9), 3097 (11). Fróes, R.L. 24064 (8), 24066 (8), 26000 (10), 26696 (10), 28719 (8), 28850 (7), 31043 (11), 34048 (10), 34236 (10), 34258 (9), 34297 (2) 34348 (10) 34597 (3), 34639 (11), IAN 100741 (10). Gentry, A. 48991 (9). Gomes, F.P. 1 (7), 5 (8), 6 (9), 7 (11), 8 (10), 26 (7), 28 (1), 31 (10), 32 (7), 33 (7), 34 (9), 35 (9). Gomes, M. 91 (11). Gottsberger, G. 12-02081981 (8), $12-$ 13081982 (8), 14-160891 (8). Guedes, M. MG 2090 (9). Henderson, A. 269 (7). Hill, S.R. 12923 (11). Huber, J. 18 (9), 3831 (4), 4964 (8), MG 1794 (9), MG 2985 (9). Irwin, H.S. 47986 (10), 47987 (10). Kulhmann, J.G. 740 (8). Leal, E.S. 91 (9), 92 (9), 101, (9), 102 (9), 103 (9), 109 (1), 116 (9), 117 (11), 121 (9), 122 (11), 123 (8), 124 (8), 142 (11), 184 (8), 201 (11), 265 (11) 266 (9), 267 (1), 273 (11), 291 (10). 292 (8), RB 499482 (9), RB 499483 (9), RB 499479 (9). Lima, J. 585 (9). Lisboa, P. 1596 (7). L.K. 18949 (9). Lleras, E. P16984 (7), P17374 (8), P17435 (9). Lobato, L.C.B. 1264 (9). Lobo, M.G.A. 219 (9). Loureiro, A. INPA 35856 (9), INPA 48029 (9), INPA 48045 (11), INPA 48404 (9), INPA 48142 (7). Luiz. MG 21907 (10). Maas, P.J.M. 6684 (10) P13023 (11). Maciel, U.R. 802 (11). Madison. PFE 45 (10), PFE 304 (7), PFE 528 (9). Magalhães, J.L. 65 (9). Marinho, L.R. 353 (7). Markgraf, F. 3808 (9). Marquete, R. 1494 (11). Martinelli, G. 15842 (11). Medeiros, H. 189 (9). Mello, F. 91 (11). Michelangeli, F.A. 1377 (6). Miranda, A.M. 1308 (11). Monteiro, O.P. 491 (9), 964 (10). Mori, S. 20705 (11). Nascimento, M.P. 365 (11). Nascimento, O.C. 174 (10), 721 (7). Oliveira, E. 3072 (9), 5197 (9), 5206 (9), 6030 (9). Oliveira, J. 43 (9), 232 (11), 896 (1). Pereira, E. 3249 (9). Pires, J.M. 103 (9), 985 (7), 3107 (8), 4858a (9), 6971 (9), 10205 (9), 10209 (9), 13073 (11), 51230 (10), 52621 (11). Plowman, T. 12140 (10), 12186 (9), 12198 (10), 12217 (8), 12291 (7). Prance, G.T. 1786 (9), 7388 (9), 7484 (8), 7629 (9), 7906 (9), 7908 (7), 8196 (8), 8558 (9), 8907 (9), 9346 (11), 9701 (7), 11017 (11), 11345 (10), 12215 (9), 12321 (11), 12548 (11), 12585 (10), 15841 (7), 16426 (8), 16430 (7), 16441 (10), 20538 (10), 21407 (7), 23770 (9), 23945 (9), 24070 (9), 25650 (9), 25706 (8), 30226 (11). Quinet, A. 1429 (7), 1621 (7), 1887 (8). Rabelo, B.V. 3721 (11). Ramos, J.F. 843 (11), 1094 (7), 1586 (11). Ribeiro, B.G.S. 152 (9). Ribeiro, J.E.L.S. 820 (10), 902 (7), 1149 (9), 1467 (8), 1481 (9), 1701 (9), 1720 (8). Rocha, A.E.S. 241 (11). Rocha, J.P.B. 743 (5). Rodrigues, R.S. MG 4032 (9). Rodrigues, W. CPF 1742 (7), 556 (9), 973 (10), 1335 (10), 1837 (10), 7100 (7). Rosa, N.A. 2731 (10). Salomão, R.P. 350 (11), 1103 (9). Santos, J.L. 251 (9). Schubert, B.G. 2176 (9). Silva, A. 46 (9), 280 (11). Silva, J.P. 401 (11). Silva, J.S.A. 12 (11). Silva, M. INPA 91932 (8), 356 (9), 2357 (8). Silva, M.B. 31 (11). Silva, M.F.F. 215 (7), 261 (7), 446 (7), 510 (7), 1430 (8), 1479 (10). Silva, M.G. 2702 (9), 4786 (11). Silva, N.T. 470 (9), 1399 (11). Silveira, M. 653 (11). Sobel. G.L. 4945 (9). Sothers, C.A. 123 (9), 331 (7), 821 (10). Sousa, G.M. 428 (10). Souza, M.A.D. 505 (9). Sperling, C.R. 6156 (11). Steward, W.C. P20226 (9), 20388 (11). Stone, A. 1 (11). Sucre, D. 10158 (11). Teixeira, L.O.A. 240 (7), 987 (7). Vicentini, A. 1159 (11). Vidal, J.C. 52 (9). Vieira, G. 459 (8). Vieira, M.S. 1 (9). Von Luetzelburg. 22810 (9), 22815 (9), 22818 (9), 23032 (10), 23711 (10). Westra, L.Y.T. 48548 (10). 